
\title{
$\mathrm{UNLV}||_{\text {LIBRARIES }}^{\mathrm{UNIVRSTY}}$
}

1987

\section{Energy Transmission into the Human Hand from Vibrating Tools}

Douglas D. Reynolds

University of Nevada, Las Vegas, reynolds@nscee.edu

Follow this and additional works at: https://digitalscholarship.unlv.edu/me_fac_articles

Part of the Mechanical Engineering Commons

\section{Repository Citation}

Reynolds, D. D. (1987). Energy Transmission into the Human Hand from Vibrating Tools. Journal of the Acoustical Society of America, 81 S71-S71.

https://digitalscholarship.unlv.edu/me_fac_articles/271

This Article is protected by copyright and/or related rights. It has been brought to you by Digital Scholarship@UNLV with permission from the rights-holder(s). You are free to use this Article in any way that is permitted by the copyright and related rights legislation that applies to your use. For other uses you need to obtain permission from the rights-holder(s) directly, unless additional rights are indicated by a Creative Commons license in the record and/ or on the work itself.

This Article has been accepted for inclusion in Mechanical Engineering Faculty Publications by an authorized administrator of Digital Scholarship@UNLV. For more information, please contact digitalscholarship@unlv.edu. 
have suggested such mechanisms as relaxation of proton-transfer equilibria occurring at ionizable residues and relaxation of solvent-solute equilibria. Though other mechanisms have been proposed, no single mechanism appears to be predominant in being responsible for ultrasonic absorption by proteins.

\section{0:00}

FF3. The contribution of absorption to tissue attenuation. Kevin J. Parker (Department of Electrical Engineering, University of Rochester, Rochester, NY 14627)

The relative contributions of ultrasonic scattering and absorption to the overall attenuation coefficient of tissues is an important issue in diagnostic and therapeutic ultrasound. This paper presents a range of experimental evidence and case studies which support the postulate that absorption dominates attenuation in soft tissues. Comparisons of tissue absorption coefficients (using thermal pulse decay) and attenuation coefficients (using radiation force insertion loss) are given, along with results of tissue homogenization experiments. Other evidence is gained from measurements of total scattered power, and clinical observations of backscatter and attenuation of focal lesions. Finally, comparisons are made of the attenuation of dilute protein solutions and whole liver specimens, in order to establish the role of multiple relaxation mechanisms at the macromolecular level in the overall attenuation coefficient of mammalian liver tissue.

\section{0:30}

FF4. Calculation of temperature elevation caused by ultrasound absorption. Wesley L. Nyborg (Physics Department, University of Vermont, Burlington, VT 05405)

It has been known for decades that ultrasound is capable of producing physiological change in man and in laboratory animals. A dominant mechanism for the change is temperature elevation resulting from sound absorption. It has been shown for some situations that the processes for heat generation and transport are understood well enough to make it feasible to predict the temperature that results from specific acoustic exposures. Thus Pond, Robinson and Lele, Carstensen, Lizzi, and others have successfully calculated intensity-time combinations required for production of recognizable lesions in mammalian tissues and other media. There is now special interest in computational methods for application to ultrasonic hyperthermia, and also to the formulation of safety criteria for diagnostic ultrasound. For the latter purpose a simplified method has been developed, based on a Green's function solution to the bio-heat transfer equation. In this paper, previous work on temperature calculations is reviewed, and recent results discussed.

\section{1:00}

FF5. Energy transmission into the human hand from vibrating tools. Douglas D. Reynolds (Department of Civil and Mechanical Engineering, University of Nevada-Las Vegas, Las Vegas, NV 89154)

A method for calculating power transmitted to the hands of operators who use vibrating hand tools is presented. Results that relate to a comprehensive multidisciplined NIOSH field study of several hundred chipper and grinder workers who used pneumatic hand tools are discussed. These results indicated that the total power in the frequency range of 6.3 to $1000 \mathrm{~Hz}$ transmitted to the hand ranged from 1080 to $7230 \mathrm{~J} / \mathrm{s}$ for the chisel and from 0.852 to $157 \mathrm{~J} / \mathrm{s}$ for the handle of chipping hammers. For pneumatic grinders the power transmitted to the hands of the tool operators was in the range of 0.00658 to $0.235 \mathrm{~J} / \mathrm{s}$ over the same frequency range. 